\title{
Power of Branding*
}

\section{NIKE}

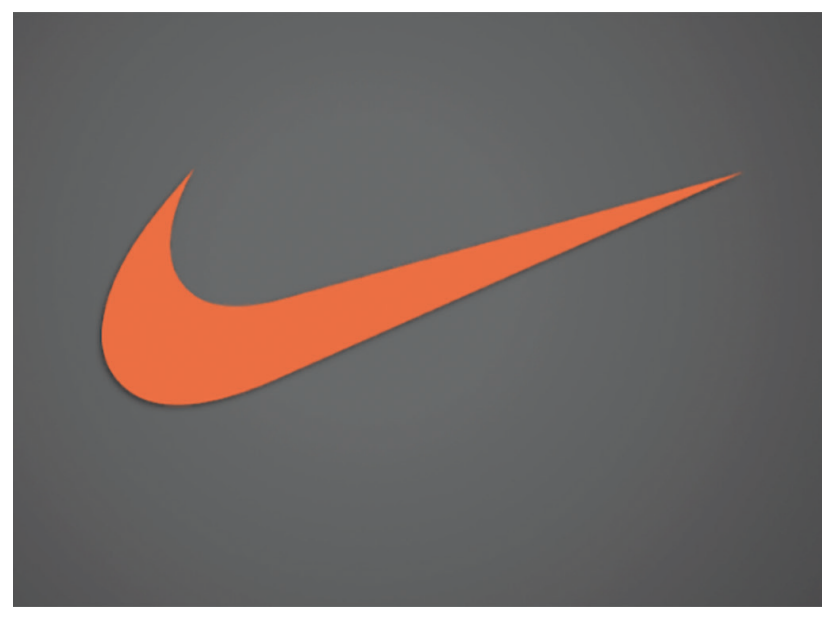

Does anybody know what this symbol means?

It is one of the most recognizable symbols of our times.

Can we acknowledge that this symbol is supposed to say amazing things about people associated with it, especially athletes.

Yet, all of us intellectuals have no clue what this Swoosh means or stands for!

\section{JUST DO IT}

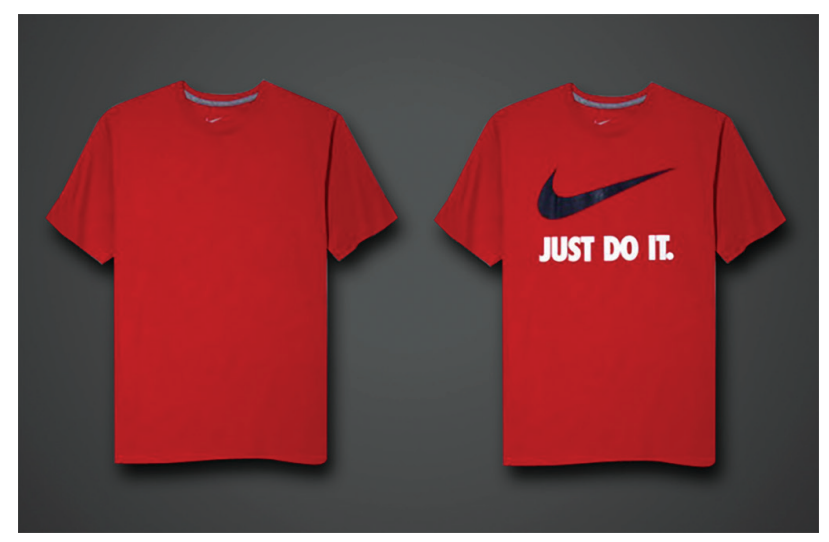

But we would drive across town, wait in line for hours, and pay almost three times to buy a T-shirt with this check mark than a similar T-shirt of the same cotton and style without it.

The amazing part is we do not even know what NIKE stands for! Even the way it should be pronounced: Should not NIKE be "NIKE" and not NIKI.

What we need to come to understand is NIKE did not let this happen by chance. They did not say let's hope the world understands WHO WE ARE AND WHY WE MATTER.

They said we are going to decide for them, we are going to put the answer in the mind of our audiences so that when they see us, they think exactly what we want them to think about us.

We are all making decisions about what BANDS to listen to, what political parties to serve, what organizations to associate with, because we know that when someone sees our brands, they are going to think something specific about us that we want them to think.

They are not the only company to figure this out, let me give you another example.

*Excerpts from the talk delivered by Mr Shivkumar Menon (Global Marketing Director-lan Donald School) at the Regional Congress held at Sarajevo, Bosnia-Herzegovina 


\section{McDONALD'S}

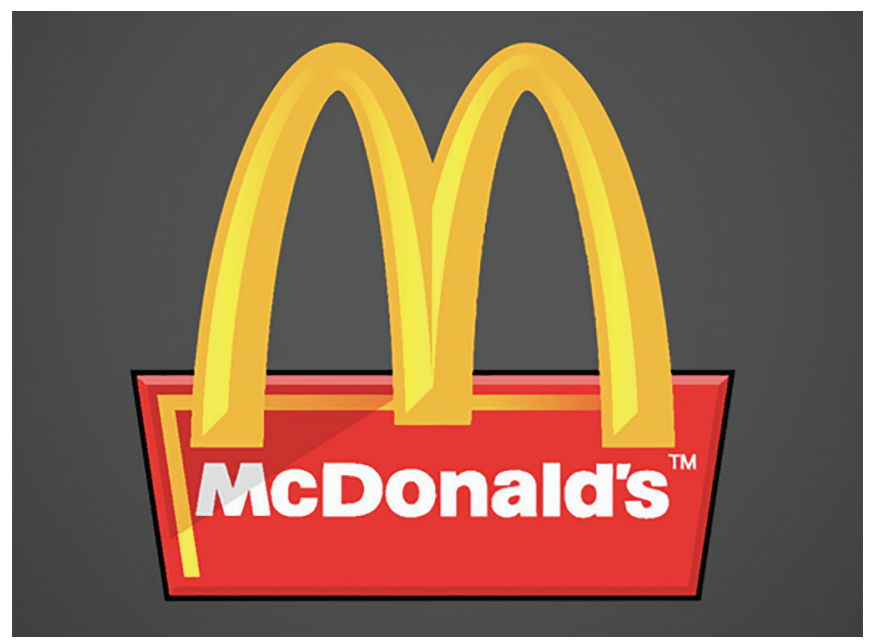

Does anybody think that big MC is BIG? Does anybody know of any taste test that McDonald's has ever won? NEVER! Yet, it is the fastest growing food franchise in the history of the food franchise business. No one can beat McDonald's. WHY? So let us analyze what McDonald's has to offer.

In the 1980s when Soviet Union still existed in the traditional communist sense, McDonald's decided to set up a facility there.

Now, McDonald's worldwide has a policy that wherever they set up their facility they hire local talent, rear their cows locally, grow their lettuce locally. In this case, all Russian.

So what were the Russians waiting in line for 3 days, FOR 3 DAYS, to be served by Russians in a Russian-built facility with Russian meat and grains?

What were they waiting to bite into? WHAT WAS THE FEELING THEY WERE SEEKING?

CAPITALISM, FREEDOM, AMERICANO, SELF-EXPRESSION - MCDONALD'S HAS NEVER SOLD HAMBURGERS, IT SELLS A SENSATION, A NOTION OF AMERICAN FAMILY.

You can disagree or you can go to PARIS and realize the fastest growing coffee shops in Paris is MAC CAFÉ, MCDONALD'S MAKING COFFEE.

Is it about the price of the coffee??? Is it about the size of the cup??? Is it about the taste of the coffee???

"No."

It is about the experience, it is about the feeling you get in the presence of the brand.

Let me give another example. Is Mickey the only mouse in the world?

\section{MICKEY MOUSE}

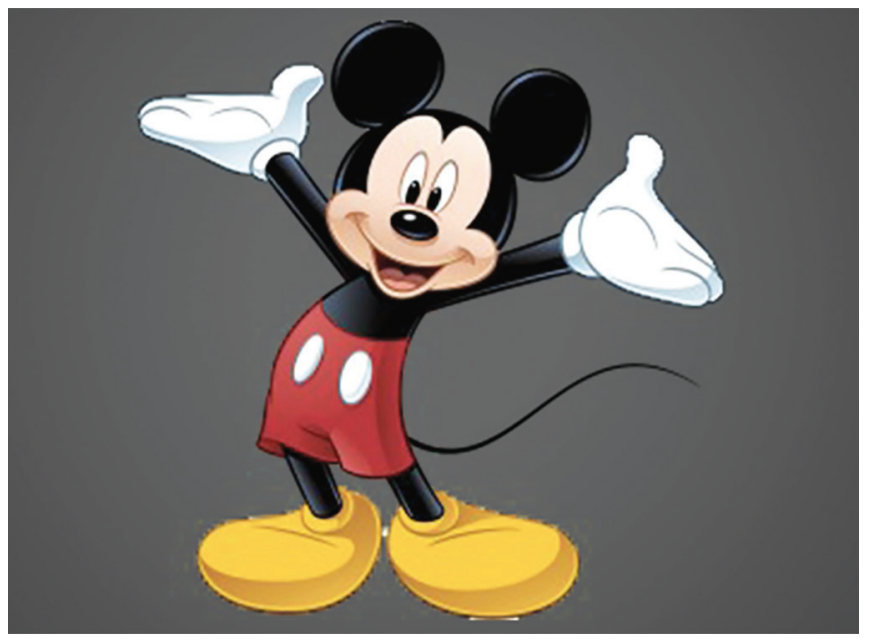


Is Mickey the only mouse in the world? Is Mickey the only mouse in the world?

Everything about this mouse is quite whacked out. Be it his friends, ducks, dogs, and whatever or His girlfriend who he has been dating for 60 years now and nobody cares to ask what his intent is, whether he is going to get married to her, he is not the only cartoon character that existed or exists, yet he is the king.

So, I do not know if you know, you could go to the Universal Studios if you buy a can of coke for about $15 \$$. Do you know how much it takes to go to Disneyland? 100\$.

Both have roller coasters, cartoon characters, entertainment of different kinds, food and the works, so why the difference?

The person clearing your trash at Universal Studios is called Janitor. Do you know what the person clearing trash at Disney is called???? "Cast Member." Why? What does that mean?

He is telling you a story; he is putting on a show, so that when you are in the magic kingdom you feel "MAGICAL." You can find roller coasters, deserts, entertainment anywhere else for cheaper but at Disney you feel Magical. Do you think it is by accident or by Chance? "NO."

"This is the Power of BRANDING"

I do not know if you all know I started our company 10 years ago. We consult large, small Indian multinational health care companies on brand strategy. So we deal with brands, brand managers on a daily basis. In all our interactions with these organizations and their people, so-called custodians of the brands, I found one common thing. One common thing that differentiates one organization from another. One common thing that determines the success or failure of an "Organization" or a "Brand" is the presence of a LEADER.

The leader is not the one by classical definition, the President, the CEO, or the CFO, but one who believes. The one who sincerely and emotionally believes in the story. The problem with organization is that they have leaders who are number crunchers, leaders who are administrators but not leaders who believe, Believe with every fiber of their BEING.

Whether it is Steve jobs, Richard Branson, or Nelson Mandela, whoever you pick, it is not functionally what they did that we admire but what they believed and never compromised anything for their belief. When every pore of our being believes the story, everything that we think, we speak, or do will be an extension of the belief. And true belief is very contagious and spreads like fire.

We have great leaders in our directors of all our 109 schools. But let's believe in the story of brand IAN DONALD. Let's tell the world WHO WE ARE AND WHY WE MATTER. So that when they see us, they think exactly what we want them to think about us.

Great Brands, Great Faith, Great Organizations are not built by chance, so let's not leave it to chance.

Shivkumar Menon 